\title{
Hunting in Extremadura-Profiles of the Hunter on the Basis of His Movements
}

\author{
Luz-María Martín-Delgado ${ }^{1, *(\mathbb{0})}$, Juan-Ignacio Rengifo-Gallego ${ }^{2} \mathbb{D}$ and \\ José-Manuel Sánchez-Martín ${ }^{1}$ D \\ 1 Faculty of Business, Finance and Tourism, University of Extremadura, 10071 Cáceres, Spain; \\ jmsanche@unex.es \\ 2 Faculty of Letters, University of Extremadura, 10071 Cáceres, Spain; irengifo@unex.es \\ * Correspondence: luzmariamd@unex.es
}

Received: 26 March 2020; Accepted: 19 April 2020; Published: 21 April 2020

\begin{abstract}
Hunters make a large number of trips during the hunting season all over the world due to the irregular distribution of hunting species. The proliferation of this kind of travel gives rise to the origin of a new kind of specific tourism, i.e., hunting tourism. Currently, the economic magnitude of this kind of travel has led to carrying out numerous studies on the subject. It has, however, been observed that most of them concentrate on the economic and environmental aspects of this activity and neglect a parameter as important as demand. Becoming familiar with the characteristics of the hunting traveller allows more appropriate management of this kind of tourism. It is for this reason that this study approaches the various profiles of hunting travellers residing in Extremadura and determines the most important characteristics of their movements. The main source of information for this research is the results obtained from distributing a questionnaire during a period of one year. These data have been processed by univariate and bivariate statistical techniques, which allow us to obtain groundbreaking results. These include, in particular, the considerable mobility of the hunter resident in Extremadura, who makes a large number of trips in order to hunt during the season, and the relationship between the number of days hunters travel, according to their income.
\end{abstract}

Keywords: hunting; movements; travellers

\section{Introduction}

Hunting has undergone a considerable transformation throughout history, which evolves from its conception as a practice based on subsistence to its current consideration as a leisure and recreational activity. This dual role already existed in Spain in the Middle Ages, which is a historical period when royalty already practised big game hunting as a leisure activity [1]. Examples of this can be found in classical hunting texts such as that written by Alfonso XI in the 14th century on hunting parties [2] and in other books published in successive centuries. During the Modern Age, big game hunting continued to be a privilege reserved for monarchs and noblemen. This situation was to change in the 19th century with the suppression of privileges in the country. From this moment on, hunting gradually ceased being a practice of subsistence to give way to a new perspective in which its leisure and sporting character came to the fore [3]. It was precisely during this century when the first international hunting trips arose in numerous countries with the major destinations being Africa and Asia, which is encouraged by the improvement in transport systems and colonisation [4]. The profiles of these first international hunters were a combination of trophy hunters [5] and naturalists, adventurers, and explorers [6]. Many of the specimens shot on these trips were exhibited in museums and, at the same time, a literature of hunting trips arose. These circumstances helped promote hunting travel, which increased considerably during the 20th century encouraged by the great improvement in infrastructures and transport [7]. 
During the 20th century, hunting became more popular with an increase in the number of hunters and hunting trips. One of the reasons for the movements of hunters to different destinations is and has been the irregular distribution of hunting species throughout the world. This is combined with the interest in enjoying experiences in different places in which the landscapes and hunting cultures may be very diverse. The increase in the number of hunters and the dissemination of these trips led to a new form of specific tourism. This is hunting tourism, which is defined by Rengifo [7] (p. 4) as being "that including the series of activities carried out by people who travel to a specific space attracted by the hunting resource with the aim of capturing specimens with sustainable criteria using different techniques and means."

A series of elements occur in this type of trips, which are described in Figure 1 and can be summarised as follows. Hunters start from an issuing centre, which is their place of residence and travel to a reception centre in which various hunting species are distributed. Among those taking part in hunting trips, two types of hunters can be identified depending on the duration of the former. One type is known as the hunter-tripper who makes day trips lasting less than $24 \mathrm{~h}$ and does not need an overnight stay at the reception centre. The second type is the hunter-hunting tourist who makes journeys lasting more than $24 \mathrm{~h}$, which implies an overnight stay at the destination.

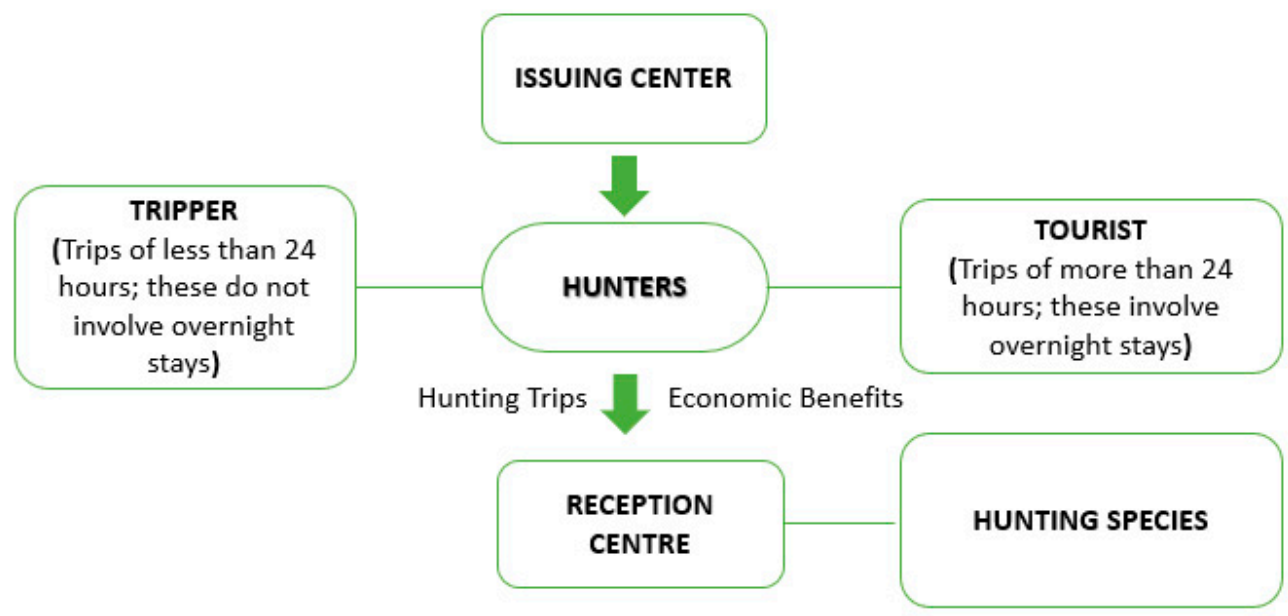

Figure 1. Conceptual diagram of hunting tourism elements.

Hunting tourism has attained considerable importance on a world scale. In this sense, the United States and Europe are the main potential issuing centres for hunters in international tourism as the result of their high purchasing power and the large number of hunters. In 2016, the number of United States citizens with a hunting licence amounted to 11.5 million [8], while, in Europe, the figure is 7 million [9]. Knowing the characteristics of the demand for hunting travelers allows the design of adequate planning and management of this type of tourism. In the case of Europe, Pinnet [10] identifies the existence of three types of hunters, according to their travel type and the expenses of these journeys.

Hunters who do not travel outside their country of residence to practise hunting make journeys within the same region, which do not generally involve overnight stays.

Hunters mainly travel within their country of residence and occasionally outside it to hunt. These journeys may involve overnight stays at their destination as they are of variable distances and the expense incurred by the hunter is intermediate.

Among hunters who habitually travel outside their country of residence to hunt, the distance travelled is the longest and involves overnight stays at the destination.

These journeys generate an important economic impact in the reception centres, which affects very diverse sectors such as the hotel trade and acts as a possible tool of economic diversification in these places [11-13]. In some specific destinations such as Africa, the role that hunting tourism plays has been amply demonstrated in two important aspects: nature conservation and its contribution to 
the local economy of rural populations. The economic resources derived from this specific form of tourism are a fundamental source of wealth for the local population living in different areas of Africa where hunting tourism has a high presence [14,15]. At the same time, a good part of this revenue has enabled numerous measures to conserve the environment [16].

The popularisation of hunting and the economic benefits it generates on a world scale have meant that this activity has currently attained considerable importance in certain rural areas. It is for this reason that the scientific studies on this subject have increased in number. The main lines of research, which have arisen at a regional, national, and international level are as follows.

On the one hand, those studies have aimed to estimate the effect of hunting tourism on specific destinations and the role it plays in the local economy of the reception centres [17-25].

On the other hand, these studies have examined the environmental implications of hunting tourism [26-34].

Lastly, a small number of studies have concentrated on the profile of the demand for this specific type of tourism $[10,35,36]$.

In short, the need for carrying out specific research into aspects of the profile of the hunting tourist can be appreciated. For this reason, the main aim of this study is to contribute scientific knowledge on a subject rarely tackled in the literature, which is known as the profile of hunters, by taking the autonomous region of Extremadura as a study area since hunting is of great importance there [37-43]. Special emphasis is placed on identifying the type of displacements resulting. In this way, the following hypotheses are raised.

Hypothesis 1 (H1). The number of days that the hunter stays away from his place of residence has a certain relationship with his monthly income, the place he travels to, and the frequency with which he hunts in public and private reserves.

Hypothesis 2 (H2). There are differences between the profile of the hunter-tripper and the hunter-tourist resident in Extremadura.

In order to approach its objective, this study is structured in various sections.

In the first place, we detail the methodology used to carry out the study, which was essentially the distribution of a survey to hunters from Extremadura. Numerous replies were obtained, which have acted as the main source of information.

Second, we expound the results obtained after applying various techniques, which have allowed us to find out the differences between the profile of the hunting tripper and the hunting tourist resident in Extremadura.

Third, a discussion is initiated in which the results generated by this research are debated.

Lastly, some conclusions are given, which are derived from carrying out the full investigation.

\section{Materials and Methods}

The methodological process has been developed in the phases described in Figure 2. First, a specific survey was designed to collect information on the different travellers' profiles. These data were integrated into a database, which was later processed using statistical techniques that have permitted innovative results to be obtained. At the same time, some of the data collected from the questionnaire as the subject of this research was integrated into Geographic Information Systems by determining the main hunting destinations preferred by hunters' residence in Extremadura.

The materials used in this research respond to two types of data: alphanumeric and cartographical data. The main source of information comes from the distribution of a questionnaire, which was designed for this research. It consisted of a series of questions in three blocks, as described in Table 1. The results of the questionnaire make up the alphanumeric information of this study. On the other hand, cartographical information from the National Geographical Institute [44] has been used. To be 
precise, the National Topographical Database at a scale of 1:100,000 draw up maps reflecting the major destinations chosen by the hunter from Extremadura at a regional and national level.

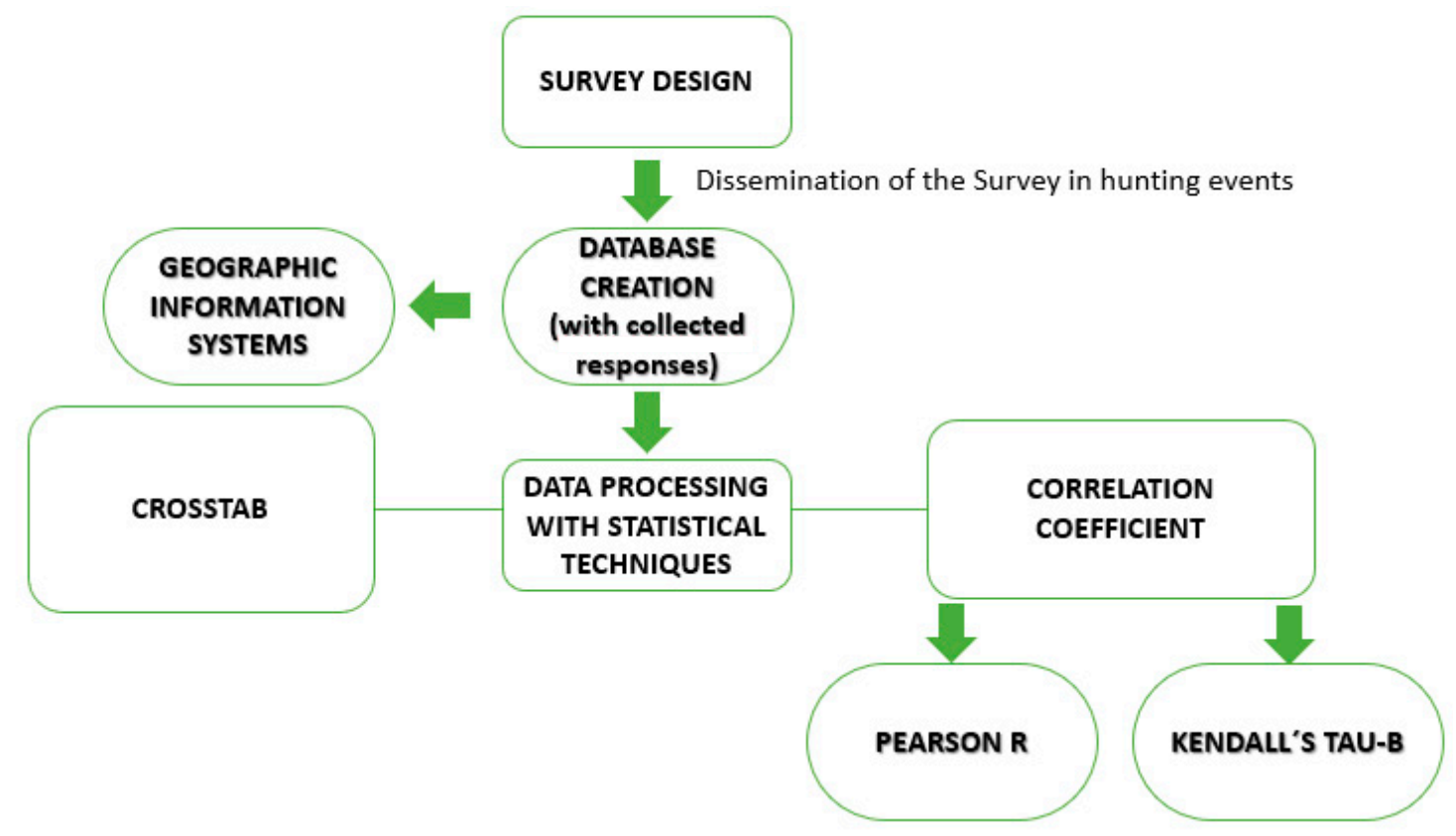

Figure 2. Methodological process.

Table 1. Blocks and questions of the questionnaire.

\begin{tabular}{|c|c|c|}
\hline Sociodemographic/Economic Profile & Movements of the Hunter & Types of Hunting \\
\hline Sex & Places where you hunt & $\begin{array}{c}\text { What types of small game hunting } \\
\text { do you practise? }\end{array}$ \\
\hline Age & $\begin{array}{l}\text { How many days do you travel to } \\
\text { hunt away from your place of } \\
\text { residence? }\end{array}$ & $\begin{array}{l}\text { What types of big game hunting } \\
\text { do you practise? }\end{array}$ \\
\hline Place of Residence & $\begin{array}{c}\text { Can you estimate the number of } \\
\text { days you stay away from your } \\
\text { place of residence during hunting } \\
\text { trips? }\end{array}$ & $\begin{array}{l}\text { How regularly do you hunt in } \\
\text { public reserves? }\end{array}$ \\
\hline Level of Studies & $\begin{array}{c}\text { What type of accommodation do } \\
\text { you choose for these overnight } \\
\text { stays? }\end{array}$ & $\begin{array}{l}\text { How regularly do you hunt in } \\
\text { private reserves? }\end{array}$ \\
\hline Employment Situation & Who do you travel with? & $\begin{array}{l}\text { Are you a member of a local } \\
\text { hunting association? }\end{array}$ \\
\hline Monthly Income & $\begin{array}{l}\text { Do you carry out activities other } \\
\text { than hunting on these trips? }\end{array}$ & \\
\hline Average Spending on Trip- & $\begin{array}{l}\text { Expense of hunting trips during } \\
\text { the last season }\end{array}$ & \\
\hline
\end{tabular}

The alphanumeric data were compiled during intense field work carried out between 15 September 2018 and 15 September 2019, which consisted of attending numerous hunting events (hunting fairs, hunters' meetings, shooting parties, etc.) and of the distribution by electronic means (Google Drive) of the questionnaire of this research (Table 2). These data were subsequently included on a database, which has allowed highly relevant information on the profile of the hunter-tripper and the hunter-tourist to be obtained as well as information on the movements of hunters from Extremadura during the 2018/2019 hunting season. Although this survey was completed by hunters who resided in the autonomous region of Extremadura and by those who did not, for this study, the replies taken as a reference were 
those living in this region at that time. Since a high number of replies were obtained, it was possible to carry out a very reliable statistical analysis.

Table 2. Data sheet.

\begin{tabular}{cc}
\hline Background & 38,273 hunting licences issued in Extremadura (2018) \\
Sample Size & 354 completed surveys \\
Sampling & Random sample \\
Truthfulness Level & $95 \%$ \\
Type of Survey & Questionnaire on paper and online distributed at various hunting events \\
and through Google Drive.
\end{tabular}

The data sheet, which appears in the following table, shows the considerable statistical reliability of this information in which for 38,273 hunting licences were issued in Extremadura in 2018 [45]. A sample size of 354 completed questionnaires was obtained. These data allow the reduction of the sample error in the worst-case scenario to $5.2 \%$ and, in the best of cases, to $3.1 \%$.

This information has been processed by means of univariate and bivariate descriptive statistical techniques such as the crosstab, which has allowed us to appreciate the differences between both traveller profiles, together with the application of the Pearson R correlation coefficient and Kendall's tau-b correlation coefficient to determine the existence or otherwise of correlation between some of the variables studied. These coefficients have been those used in this study as they were considered the most appropriate for establishing the relationships, which occur between some of the variables of this research due to their ordinal qualitative nature (45). The results of the application of these coefficients will indicate whether there is any type of association between the variables in such a way that the following situations may arise.

The coefficient is 0 , which indicates that there is no type of relationship between the variables.

The coefficient is between 0 and +1 . In this case, the variables show a positive association, i.e., the value of both variables increases at the same time.

The coefficient is between -1 and 0 . This scenario identifies a negative correlation, which means that, while the value of one variable increases, the value of the other variable falls.

Moreover, we resorted to using Geographical Information Systems for drawing up the thematic cartography.

This type of methodology has been widely used in limiting different tourist profiles [46-48], due to which it has been determined to be the most appropriate for tackling the objective put forward in this research.

\section{Results}

\subsection{Differences between the Hunter-Tripper and the Hunter-Tourist Resident in Extremadura}

Hunters resident in Extremadura make numerous trips during the hunting season essentially on three levels: regional, national, and international. Only a small proportion of those polled by this study declare that they hunt exclusively in the municipality where they live (12.4\%). The remainder of hunters who do travel do so in different ways. It is noteworthy that there are two kinds of travellers in this region depending on the duration of these trips. On the one hand, we have the hunter-trippers, the movements of whom are characterised by being to nearby destinations for a period of less than $24 \mathrm{~h}(30.8 \%)$. On the other hand, we find hunting tourists, who constitute most of the study sample $(56.8 \%)$. They travel to territories located further away from their habitual place of residence for more than one day and, therefore, need to stay overnight at the reception center. 
The number of days that the hunter from Extremadura stays away from his place of residence is determined to a certain extent by his monthly income. As the level of income increases, this leads to an increase in the number of days which the hunter spends away from his town of origin (Table 3). This situation is logical if we take into account that overnight stays involve higher expenses at the reception center. Therefore, hunters with less purchasing power decide to make trips that do not involve staying at the destination.

At the same time, the application of the Pearson $\mathrm{R}$ and Kendall's tau-b correlation coefficients has allowed the establishment of relationships between the number of days that the hunter spends away from his place of residence with other ordinal qualitative variables of this research, which provides very interesting information. The relationship between the place travelled to and the number of days the hunter stays at his destination is clear, since, when these trips are made to destinations closer to the town of residence, overnight stays are not necessary or the number of days of the stay is reduced. Due to the qualitative nature of the variable of the "places to which trips are made," it should be explained that an interval of values has been established in such a way that it has been considered where movements within the autonomous region (regional travel) involve shorter trips, while those made beyond these limits involve a greater distance to the destination. This group includes national and international journeys. The Pearson R and Kendall's tau-b correlation coefficients obtained between these variables confirm this scenario with the number of nights stayed increasing as the level of travel increases.

In addition, at the same time, among the results obtained from the application of the Pearson $\mathrm{R}$ and Kendall's tau-b correlation coefficients, the relationship between the number of nights spent away from the hunter's place of residence and the type of reserve in which hunting is practised is noteworthy. In this way, it has been appreciated how, as the frequency with which hunting is practised in public reserves (reserves with a sporting aim rather than a commercial one), the number of overnight stays falls, and, in contrast, the increase in these stays is higher among those hunters who practise their sport in private reserves (reserves with a business purpose). These data may be essentially due to the socioeconomic profile of the hunter as public reserves are administered by hunters' associations, which facilitate access to this practice to those hunters with less purchasing power. On the other hand, hunting practised in private reserves has higher economic connotations.

The analysis of the sociodemographic and economic profile of hunting travellers' residence in Extremadura has concentrated on five variables: sex, age, level of studies, employment situation, and monthly income (Table 4). The results obtained express certain differences between both profiles. In the first place, it can be seen that there are few women in the world of hunting as they account for a very small percentage of the sample studied (4.1\% of trippers, $7.8 \%$ of tourists), even though it is true that they are more numerous in the category of hunting tourists. This situation is clear from other studies, which have analysed the profile of the hunter $[35,36,49]$ as these confirm the token presence of women in hunting. On the other hand, the age group variable reflects the presence of mature hunters in both traveller profiles with few aged under 26 years old. This scenario is echoed in other places such as the province of Córdoba, where the most representative age group of hunting tourists as a whole is between 50 and 59 years of age with few young hunters [35]. However, the segmentation carried out in this study shows that there are certain differences between the age groups characteristic of the various types of hunting travellers residing in Extremadura. In this sense, in the profile of the hunting tourist, most hunters belong to the 26-to-40 age group (40.3\%), while, in the profile of the tripper, the presence of hunters aged between 41 and 55 (41.9\%) predominates. 
Table 3. Relationship between variables.

\begin{tabular}{|c|c|c|c|c|c|c|c|}
\hline \multirow{3}{*}{$\begin{array}{c}\begin{array}{c}\text { Monthly } \\
\text { Income (€) }\end{array} \\
\text { Less than } 1000\end{array}$} & \multicolumn{5}{|c|}{ Nights Spent Away from Your Place of Residence (\%) } & \multicolumn{2}{|c|}{$\begin{array}{l}\text { Association Measurements } \\
\text { (Correlations) }\end{array}$} \\
\hline & \multirow{2}{*}{$\begin{array}{c}\text { None } \\
53.0\end{array}$} & \multirow{2}{*}{$\begin{array}{c}\mathbf{1 - 5} \\
28.9\end{array}$} & \multirow{2}{*}{$\frac{6-10}{6.0}$} & \multicolumn{2}{|c|}{ Over $10 \mathrm{~N}$} & Pearson R & Kendall tau-b \\
\hline & & & & 12.1 & 83 & \multirow{5}{*}{$0.283^{* *}$} & \multirow{5}{*}{$0.226^{* *}$} \\
\hline $1001-1500$ & 45.1 & 35.9 & 11.3 & 7.7 & 142 & & \\
\hline $1501-2000$ & 28.6 & 38.8 & 24.5 & 8.1 & 49 & & \\
\hline $2001-2500$ & 30.8 & 34.6 & 11.5 & 23.1 & 26 & & \\
\hline Over 2500 & 14.3 & 34.3 & 14.3 & 37.1 & 35 & & \\
\hline \multicolumn{8}{|l|}{$\begin{array}{l}\text { Where Do You } \\
\text { Hunt? }\end{array}$} \\
\hline $\begin{array}{c}\text { Only in the } \\
\text { municipality } \\
\text { where you live }\end{array}$ & 100 & 0 & 0 & 0 & 44 & \multirow{4}{*}{$0.540^{* *}$} & \multirow{4}{*}{$0.488^{* *}$} \\
\hline $\begin{array}{c}\text { In the } \\
\text { municipality } \\
\text { where you live } \\
\text { and in others of } \\
\text { your } \\
\text { autonomous } \\
\text { region }\end{array}$ & 56.7 & 34.2 & 5.8 & 3.3 & 120 & & \\
\hline $\begin{array}{l}\text { In your } \\
\text { autonomous } \\
\text { region and in } \\
\text { others }\end{array}$ & 22.0 & 44.1 & 18.6 & 15.3 & 145 & & \\
\hline $\begin{array}{l}\text { In Spain and } \\
\text { other countries }\end{array}$ & 16.3 & 16.3 & 18.6 & 48.8 & 43 & & \\
\hline
\end{tabular}

\begin{tabular}{|c|c|c|c|c|c|c|c|}
\hline $\begin{array}{c}\text { How Often Do } \\
\text { You Hunt in } \\
\text { Public } \\
\text { Reserves? }\end{array}$ & & & & & & & \\
\hline Never & 27.9 & 23.3 & 25.6 & 23.2 & 43 & \multirow{4}{*}{$-0.341^{* *}$} & \multirow{4}{*}{$-0.313^{*-x}$} \\
\hline Sometimes & 19.4 & 35.5 & 19.3 & 25.8 & 62 & & \\
\hline Habitually & 35.5 & 40.0 & 13.6 & 10.9 & 110 & & \\
\hline Always & 59.9 & 29.9 & 3.1 & 7.1 & 127 & & \\
\hline
\end{tabular}

\begin{tabular}{|c|c|c|c|c|c|c|c|}
\hline $\begin{array}{c}\text { How Often Do } \\
\text { You Hunt in } \\
\text { Private } \\
\text { Reserves? }\end{array}$ & & & & & & & \\
\hline Never & 83.9 & 12.9 & 0.0 & 3.3 & 31 & \multirow{4}{*}{$0.311^{* *}$} & \multirow{4}{*}{$0.292^{* *}$} \\
\hline Sometimes & 54.0 & 35.0 & 8.0 & 3.0 & 100 & & \\
\hline Habitually & 27.8 & 38.6 & 16.1 & 17.5 & 137 & & \\
\hline Always & 33.7 & 27.3 & 15.6 & 23.4 & 77 & & \\
\hline $\begin{array}{c}\text { Level of } \\
\text { Significance }\end{array}$ & & & & & & ${ }^{*} 0.05$ & $* * 0.01$ \\
\hline
\end{tabular}

Level of significance: this parameter allows to determine the level of statistical confidence of the results obtained. When this value is ${ }^{*} 0.05$ the statistical confidence is $95 \%$ with an error of $5 \%$; while a value of ${ }^{* *} 0.01$ determines a higher degree of confidence at 99\%. Sociodemographic and Economic Profile. 
Table 4. The sociodemographic and economic profile of hunting travellers.

\begin{tabular}{|c|c|c|}
\hline Sex & Tripper (\%) & Tourist (\%) \\
\hline Female & 4.1 & 7.8 \\
\hline Male & 95.9 & 92.2 \\
\hline \multicolumn{3}{|l|}{ Age Group } \\
\hline Under 18 & 2.7 & 1.4 \\
\hline $18-25$ & 14.2 & 11.7 \\
\hline $26-40$ & 16.9 & 40.3 \\
\hline $41-55$ & 41.9 & 24.7 \\
\hline $56-65$ & 16.9 & 17.0 \\
\hline Over 65 & 7.4 & 3.9 \\
\hline \multicolumn{3}{|l|}{ Level of Studies } \\
\hline Low & 52.0 & 34.0 \\
\hline Intermediate & 31.1 & 27.2 \\
\hline Higher education & 16.9 & 38.8 \\
\hline \multicolumn{3}{|l|}{ Employment Situation } \\
\hline Student & 10.8 & 6.8 \\
\hline Unemployed & 10.8 & 2.0 \\
\hline Working for an employer & 34.5 & 44.7 \\
\hline Civil servant & 8.8 & 9.2 \\
\hline Self-employed & 23.6 & 26.2 \\
\hline Retired & 11.5 & 9.7 \\
\hline Other & 0.0 & 1.4 \\
\hline \multicolumn{3}{|l|}{ Monthly Income (€) } \\
\hline Under 1000 & 29.7 & 19.0 \\
\hline 1001-1500 & 43.2 & 37.9 \\
\hline 1501-2000 & 10.1 & 17.0 \\
\hline $2001-2500$ & 5.4 & 8.7 \\
\hline Over 2500 & 3.5 & 14.5 \\
\hline Don't Know/No Answer/Refused & 8.1 & 2.9 \\
\hline
\end{tabular}

Hunting travellers residing in Extremadura are characterised by having a low formative level, even though their differences can be appreciated between the profile of the hunter-tripper and that of the hunter-tourist. Furthermore, 52\% of the sample of hunting trippers shows a low formative level compared with the hunting tourist where the figure falls to $34 \%$. At the same time, it can be observed that a large number of hunting tourists have a high formative level, which is nearly $39 \%$ of the study sample. The more educated profile of hunting tourists may be due to the fact that higher education generates access to scales of jobs with a higher level of monthly income. Therefore, this higher purchasing power allows us to make trips involving overnight stays at the destinations. The data of the monthly income variable confirm this situation as they reflect the higher income of hunting tourists. Despite the considerable differences that can be appreciated in both traveller profiles, these do not seem to appear in the employment situation where very similar results have been obtained. The presence of hunting travellers working for an employer stands out as they constitute a large proportion of the sample together with the self-employed.

\subsection{Major Hunting Destinations of the Hunter from Extremadura}

The trips made by hunters from Extremadura during the hunting season fall into three categories: regional $(38.9 \%)$, national $(47.1 \%)$, and international (14.0\%). Regional movements include those of hunters who move within their own municipalities and others of the autonomous region of Extremadura. On the other hand, the sample of national travellers includes hunters who travel within their autonomous region and also make numerous trips to other Spanish regions. Lastly, we have a 
third group of travellers, which move within Spain and in other countries. This part of the sample, thus, includes international travel. Table 5 reveals the considerable differences between the destinations chosen by the two traveller profiles chosen. In the case of the hunter-tripper, movements within the autonomous region constitute the majority with national travel being of lesser importance (33.4\%). The duration of the trip made by the hunting tripper is characterised by lasting less than 24 hours. This situation means that international travel is of minor importance for this traveller type (6.4\%). In this case, it is understood that this low percentage is related to Portugal, which borders on Extremadura. For their part, national travel is most representative among hunting tourists $(5.2 \%)$ compared with a small part of the sample of this traveller type who choose to move about within Extremadura. The increase in the duration of the journey and the necessary overnight stays at the hunting destination mean that international travel is frequent for these hunters. A total of $17.9 \%$ of those polled in this group declare that they travel outside Spain.

Table 5. Places where the hunting traveller from Extremadura hunts.

\begin{tabular}{ccc}
\hline & Tripper (\%) & Tourist (\%) \\
\hline In the municipality in which you live and & 62.4 & 25.9 \\
in others of your autonomous region & 29.4 & 56.2 \\
In your autonomous region and in others & 6.4 & 17.9 \\
In Spain and in other countries & 1.8 & 0.0 \\
Don't Know/No Answer/Refused & & \\
\hline
\end{tabular}

Figure 3 represents the main regional destinations selected in the study sample. In the first place, the impact of hunting in the rural milieu attracts our attention as practically all rural areas have been chosen as a destination by the hunting traveller from Extremadura. At the same time, it can be appreciated that the major urban areas do not share this importance as reception centres for hunters from Extremadura with the exception of the city of Cáceres. Despite the fact that this municipality appears as a destination, only between $5 \%$ and $15 \%$ of the sample declare that they have travelled there to hunt when compared with more than $30 \%$ of hunters who have chosen rural districts such as Monfragüe and La Vera. Moreover, these territories appear as the main hunting destinations in the region. This importance may be due to the clear vocation for big game hunting of both districts [50] as this type of hunting is one of the main interests of the hunting traveller. This vocation can also be found in other districts such as Villuercas-Ibores-Jara and the Sierra de San Pedro-Tajo Internacional, which gives rise to forming the second group of destinations. These are joined by the territory of La Serena, which differs from the remainder by showing a clear vocation for small game hunting. Despite the predominance of these areas, trips are made over practically all of Extremadura, even though the remainder of the districts are less affected by this kind of trip.

In addition to the considerable number of movements of hunters within their autonomous region, there is a significant amount of travel beyond the borders of Extremadura (Figure 4). On a national scale, the favourite hunting destinations of hunters from Extremadura show the importance of geographical proximity with regard to the place of origin in such a way that these territories share a common characteristic. They are autonomous regions bordering on Extremadura. Among these destinations, Castilla-La Mancha stands out since it is chosen by more than 50\% of travellers within Spain. Castilla y León is also prominent. The importance of these autonomous regions as hunting destinations has also been found in studies carried out on a national scale [51] due to the multitude of hunting species present in both territories. The remainder of the Spanish autonomous regions are practically ignored by the study sample of travellers within Spain.

International travel is engaged in by a small proportion of the sample of travellers from Extremadura (14.0\%). The main international destinations are Africa (37.5\%), Europe (62.5\%), and America (8.3\%). As can be seen, which was the case with travel within Spain's proximity to the 
destination, is a characteristic parameter of the demand from hunting travellers, since the most popular international destinations are Europe and Africa.

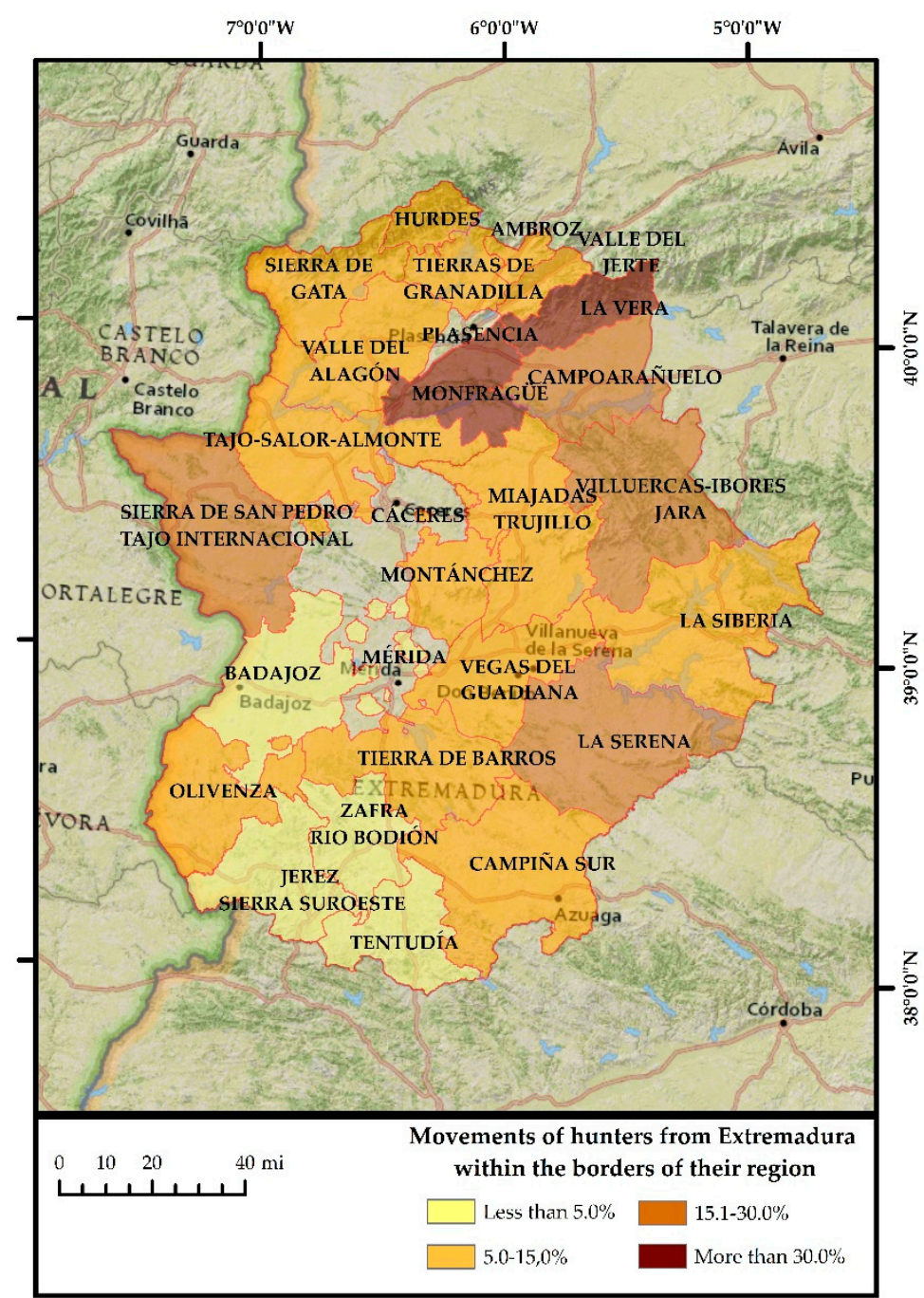

Figure 3. Movements of hunters from Extremadura within the borders of their region.

The hunter devotes a considerable number of days to travelling in order to hunt. A large proportion of the sample declared that they travel for more than 30 days on different hunting trips. This confirms the great mobility of hunters if we take into account that the general hunting period is only during the winter. At the same time, it should be specified that, during this period, as a rule, the days when hunting is permitted are restricted to weekends and holidays, to which Thursdays are added for certain forms of hunting [52]. Although there are no significant differences between the number of days on which the hunter-tripper and the hunting tourist travel during the hunting season, the data obtained show that the latter type of traveller appears to do so for a larger number of days, with more than $57 \%$ declaring that they leave their place of residence for more than 30 days when compared with $35.1 \%$ of hunter-trippers.

During these journeys, hunting tourists make numerous overnight stays, which vary between one and 10 days. These stays are made in various types of tourist accommodation. Table 6 reveals the preference of the hunting tourist for the categories of casas rurales, rural hotels, and hotels from one to three stars. This situation may be due to the lack of other types of accommodation at the destination, since, which have been observed throughout the study, the main regional reception centres are located in rural areas where rural accommodation tends to predominate. At the same time, free lodging in 
private houses belonging to friends or relations is very frequent since it accounts for more than $25 \%$ of the sample. The remainder of the types are chosen by a low proportion of the hunters with the minor presence of tourist apartments being noteworthy.

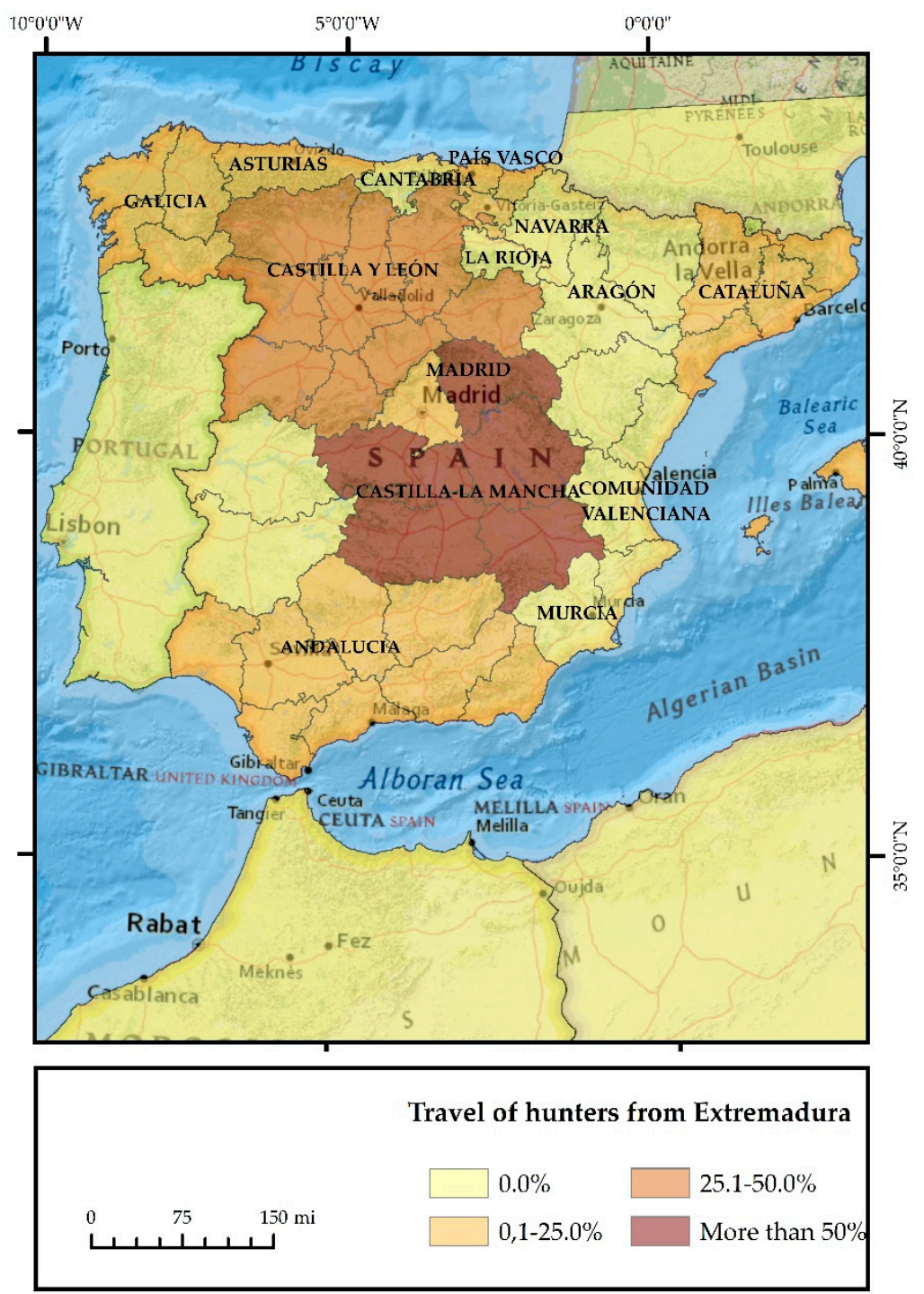

Figure 4. Travel of hunters from Extremadura.

Since hunting is strongly gregarious in nature [10], travelling alone is infrequent in this specific form of tourism (Table 6). Travelling with friends is one of the categories preferred by both traveller profiles and is very common among hunting tourists (67\%). Second, travelling as a family also stands out even though certain differences occur between hunting trippers $(18.6 \%)$ and hunting tourists (30.1\%). This lower proportion of travel as a family among hunting trippers may be due to the short duration of these journeys, which conditions the presence of people who are not hunters. This situation is reflected in the participation of hunter-trippers in activities other than hunting, where practically $58 \%$ of the sample declare that they travel exclusively to hunt and do not carry out any other activities. The opposite situation is found in the journeys of the hunting tourist who frequently carries out activities other than hunting, such as enjoying local gastronomy (46\%) and practising rural tourism (40\%). Other activities such as cultural visits or visits that protected natural spaces are less prevalent for both profiles of travellers. Despite this, the role that may be played by hunting tourism can be appreciated. It helps eliminate the seasonality characteristic of other tourist types, as the hunting season falls in winter to coincide with a reduction in demand in destinations such as Extremadura. On these journeys, hunters' 
expenses are considerable (food, transport, accommodation, etc.) since, according to the data obtained in this study, they attain $800 €$ per person in the case of the hunting tripper and $1182 €$ in that of the hunting tourist.

Table 6. Travel characteristics.

\begin{tabular}{|c|c|c|}
\hline How Many Days Do You Travel Per Season to Hunt? & Tripper (\%) & Tourist $(\%)$ \\
\hline $1-10$ & 23.7 & 12.1 \\
\hline $11-20$ & 13.5 & 17.0 \\
\hline $21-30$ & 16.2 & 13.6 \\
\hline Over 30 & 35.1 & 57.3 \\
\hline DK/NA/REF & 11.5 & 0.0 \\
\hline Overnight Stays & \multicolumn{2}{|c|}{ Tourist $(\%)$} \\
\hline $1-5$ & \multicolumn{2}{|c|}{56.8} \\
\hline 6-10 & \multicolumn{2}{|c|}{20.4} \\
\hline Over 10 & \multicolumn{2}{|c|}{22.8} \\
\hline Type of Tourist Accommodation & \multicolumn{2}{|c|}{ Tourist (\%) } \\
\hline Private house of friends or relatives & \multicolumn{2}{|c|}{25.2} \\
\hline Casa rural & \multicolumn{2}{|c|}{30.1} \\
\hline Rural hotel & \multicolumn{2}{|c|}{24.8} \\
\hline 1- to 3-star hotel & \multicolumn{2}{|c|}{35.5} \\
\hline 4- to 5-star hotel & \multicolumn{2}{|c|}{12.1} \\
\hline Tourist apartment & \multicolumn{2}{|c|}{6.8} \\
\hline On the estate where you hunt & \multicolumn{2}{|c|}{11.2} \\
\hline Other & \multicolumn{2}{|c|}{17.0} \\
\hline Who do you Travel With? & Tripper (\%) & Tourist $(\%)$ \\
\hline Friends & 32.4 & 67.0 \\
\hline Family & 18.6 & 30.1 \\
\hline Alone & 11.0 & 11.7 \\
\hline As a couple & 1.4 & 18.0 \\
\hline Other & 1.4 & 2.4 \\
\hline DK/NA/REF & 13.1 & 0.0 \\
\hline \multicolumn{3}{|l|}{ Activities Other than Hunting } \\
\hline None & 57.9 & 16.1 \\
\hline Gastronomic tourism & 15.9 & 46.8 \\
\hline Rural tourism & 10.3 & 40.0 \\
\hline Visits to protected natural spaces & 2.1 & 17.6 \\
\hline Cultural visits & 2.1 & 25.4 \\
\hline Other & 0.0 & 0.5 \\
\hline $\mathrm{DK} / \mathrm{NA} / \mathrm{REF}$ & 15.2 & 3.4 \\
\hline Average expense per person & $800 €$ & $1182 €$ \\
\hline
\end{tabular}

\subsection{Hunting Types}

Hunting is very widely practised in Extremadura, where more than $87 \%$ of the surface area is considered suitable for this activity. In addition, it has a total of 24 species of small game and seven of big game (Sus Scrofa, Cervus Elaphus, Capreolus Capreolus, Capra Pyrenaica, Dama Dama, Ammotragus Lervia, Ovis Orientalis Musimon).These hunting grounds belong to different categories, which are described in current legislation [53] to reflect the existence of two hunting models: public and economic. The public model is developed on land considered to be public reserves. The aim of this is to facilitate access under conditions of social equality to all hunters from Extremadura. This type of reserve is administered by local hunters' associations, which are distributed all over the region. On the other hand, the economic model takes the form of private game preserves in which practising hunting is more expensive. This situation determines the frequency with which the two types of travellers 
analysed in this study hunt in each of these enclosed spaces. In this sense, due to the fact that the profile of the hunting tripper is mainly characterised by earning less income than the hunter-tourist, one can appreciate that these travellers tend more to hunt in public reserves (Table 7). Furthermore, $51.4 \%$ of the sample of hunting trippers declare that they always hunt in public reserves compared with $17.5 \%$ who do so in private reserves. This intensity with which the tripper hunts in public reserves shows considerable differences with regard to the profile of the hunting tourist, who is characterised by his greater presence in private preserves, according to the data expounded in this research. Despite this, the latter type of traveller also declares that he habitually hunts (34.5\%) in public preserves. There are, thus, considerable inequalities in access to hunting lands among both types of travellers.

Table 7. Types of hunting.

\begin{tabular}{|c|c|c|}
\hline Frequency of Hunting in Public Reserves & Tripper (\%) & Tourist $(\%)$ \\
\hline Never & 8.1 & 15.0 \\
\hline Sometimes & 8.8 & 24.3 \\
\hline Habitually & 26.4 & 34.5 \\
\hline Always & 51.4 & 24.7 \\
\hline DK/NA/REF & 5.3 & 1.5 \\
\hline \multicolumn{3}{|l|}{ Frequency of Hunting in Private Reserves } \\
\hline Never & 17.6 & 2.4 \\
\hline Sometimes & 36.5 & 22.3 \\
\hline Habitually & 26.4 & 48.1 \\
\hline Always & 17.5 & 24.8 \\
\hline $\mathrm{DK} / \mathrm{NA} / \mathrm{REF}$ & 2.0 & 2.4 \\
\hline \multicolumn{3}{|l|}{ Do You Belong to a Local Hunters' Association? } \\
\hline Yes & 87.2 & 67.5 \\
\hline No & 12.8 & 32.0 \\
\hline DK/NA/REF & 0.0 & 0.5 \\
\hline \multicolumn{3}{|l|}{ Types of Small Game Hunting } \\
\hline Individual or group pursuit & 73.5 & 71.9 \\
\hline Fixed stand & 49.0 & 60.8 \\
\hline Fox hunting & 37.4 & 41.7 \\
\hline Dogs in a burrow & 26.5 & 23.1 \\
\hline Beating small game in limited areas & 24.5 & 36.7 \\
\hline Releasing for immediate shooting & 15.0 & 31.2 \\
\hline Partridge beating & 12.9 & 23.6 \\
\hline Partridge with decoy & 10.2 & 14.6 \\
\hline With greyhounds and other dogs for pursuit & 6.1 & 8.6 \\
\hline \multicolumn{3}{|l|}{ Types of Big Game Hunting } \\
\hline Hunting party & 68.7 & 77.9 \\
\hline Waiting & 44.9 & 59.3 \\
\hline Beating & 41.5 & 45.2 \\
\hline Beating in limited areas & 30.6 & 39.7 \\
\hline Stalking & 19.0 & 36.7 \\
\hline Bow and arrow & 1.4 & 0.5 \\
\hline
\end{tabular}

The types of hunting that may be practised in this region are described in current legislation [53], which recognises the existence of nine types of small game hunting and seven types of big game hunting. The results obtained do not show great differences between the occurrence of these types in the profiles of the hunting traveller (Table 7). However, the data provide very interesting information on the main types practised by both profiles. The great importance in small game hunting of the practice of individual or group pursuit and in big game hunting of the hunting party is noteworthy. 


\section{Discussion}

Hunters make a large number of trips with the aim of shooting different hunting specimens due to several factors. These include the irregular distribution of hunting species, their abundance, and the interest in enjoying new experiences. The duration of these trips allows us to establish two types of travellers: hunter-trippers and hunting tourists. At the same time, these movements take place on three levels (regional, national, and international), which coincides with that already described internationally [10]. This has given rise to a national and international hunting market with its supply and demand and with companies who provide the necessary services. All this data is known mainly through indirect sources (magazine reports, specialised fairs, hunters' clubs), there is a significant lack of knowledge through primary sources or direct surveys of hunters. This study provides knowledge on this issue. First, the results obtained show the high mobility of Extremaduran hunters, which is a feature that can be extended to hunters from other countries around us. In addition, the results obtained in this study prove the relationship that exists between the level of income and the distance travelled in such a way that, as the monthly income of the hunter increases, the distance travelled also appears to increase. This confirms the first hypothesis of the study. Despite this, it should be stressed that all travel irrespective of its level has a common characteristic, i.e., the preferential choice of destinations near the place of residence. The main hunting destinations chosen by the hunters of the study sample are, therefore, the regions bordering on Extremadura and countries near Spain, barring exceptions [36]. However, it must be pointed out that hunters can make large journeys carried by the presence of hunting species in specific geographical areas. This may be the case for hunters arriving in Extremadura, and other parts of Spain from countries around the world, to hunt the wild goat (Capra pyrenaica), which is an endemic species of the Ibérica peninsula.

Among the results obtained, our attention was drawn by the considerable number of trips, which are made by hunters from Extremadura during the hunting season. A large proportion of those polled travel over 30 days per season. During these movements, they incur significant expenses due to their overnight stays at the destination and carrying out activities other than hunting, to participation in the day's hunting, and to the use of means of transport, among others. These expenses assume a substantial income, which is essentially generated by the hunting destinations. In many cases, the destinations are located in rural areas, which are depressed from a demographic and economic perspective. Hunting, therefore, helps to stimulate the local economy of hunting destinations [11,17,25]. Moreover, hunting is practised in the winter months, which is when the demand from other tourist types falls. For this reason, hunting tourism plays an important role, helping to reduce the seasonality of other tourist types and acting as a support for demand in the low season. In this sense, it can be mentioned that Extremadura is an eminently rural region suffering from serious problems of depopulation, unemployment, low birth rates, and aging [54]. For this reason, the sustainable use of endogenous resources can help mitigate the situation. The movements of the hunter from Extremadura within the borders of his region are very frequent among those polled, which means that they help generate income in the said region. For these movements, we should add those starring hunters from other regions and countries. The income deriving from these movements together with that generated by the remainder of the activities of the hunting sector amounted to more than 385 million euros for the last hunting season [49]. These data confirm the role played by hunting in the local economy.

From a socioeconomic perspective, the results obtained reveal that few women are present in the hunting scenario as has been found by other studies [35,49]. Despite this, it appears that the number of women involved is gradually increasing [55]. The incorporation of women to the world of hunting may lead to an increase in the number of licences and help to achieve the generational transition, which is currently a major challenge for the autonomous region of Extremadura. At the same time, it must be stressed that women in the world of hunting have played a secondary role. In hunting tourism, they have acted as companions [35] and this situation should be taken into account when providing activities to complement this kind of demand. 
The results obtained in this study are groundbreaking in that no other similar research has previously been carried out in Extremadura and other Spanish autonomous regions. This contribution to knowledge becomes a useful tool for management and planning, including taking measures to generate the sustainable exploitation of hunting species. Nevertheless, this research has a series of limitations, essentially in analyzing the mobility of the travellers. The small number of replies obtained from the same issuing centre to different reception centres has prevented the development of this mobility analysis. For this reason, a future line of research is a more detailed mobility analysis to allow the determining of tourist routes in this type of tourism.

\section{Conclusions}

The data expounded in this research allow the confirmation of two types of travellers among hunters of Extremadura: the hunter-tripper and the hunter-tourist. These two profiles are defined differently, which we explain below.

Hunter-trippers are characterised in general terms by having a lower formative level, lower income, choosing public reserves, and hunting in areas near their place of residence.

Hunter-tourists generally have a higher formative level, higher income, mainly choose private reserves, engage in activities to complement hunting, and show a stronger trend to travel to different areas (Extremadura and other autonomous regions) and, in some cases, outside Spain.

Likewise, other conclusions can be gathered from the survey carried out.

- From a socioeconomic perspective, it can be appreciated that few women are to be found in either profile, even though it should be specified that their presence is increasing in the sample of hunting tourists.

- As far as age is concerned, the profile is that of a mature hunter with few under 26 years of age.

- As for movements during the hunting season, a large proportion of the hunters of the sample declare that they travel more than 30 days. During this large number of days, the hunting tourist stays overnight, spending between 1 and 10 days away from home. These overnight stays take place in various types of tourist accommodation, in particular in rural accommodation and hotels from 1 to 3 stars.

- Hunters tend to travel in company. Trips with friends and family stand out.

- The journeys of hunters from Extremadura during the 2018/2019 hunting season generated considerable income with certain differences between the two traveller profiles detected. The average expense per person incurred by the hunting tripper amounted to $800 €$. The figure increases to $1182 €$ in the case of the hunting tourist. These data reveal the role played by hunting as an economic activity and the considerable income it contributes in tourist destinations.

- Lastly, as far as practising the main types of hunting is concerned, no major differences were found between both types of travellers. The prominence of individual pursuit and hunting parties should be emphasised.

Lastly, after carrying out the research, the two initial hypotheses put forward can be accepted. The results show the differences between the two traveller profiles and the relationship between some of the study variables.

Author Contributions: Conceptualization, L.-M.M.-D. and J.-I.R.-G. Methodology, L.-M.M.-D., J.-I.R.-G., and J.-M.S.-M. Formal analysis, L.-M.M.-D., J.-I.R.-G., and J.-M.S.-M. Investigation, L.-.M.-D., J.-I.R.-G., and J.-M.S.-M. Resources, L.-M.M.-D., J.-I.R.-G., and J.-M.S.-M. Data curation, L.-M.M.-D. Writing-original draft preparation, L.-M.M.-D., J.-I.R.-G., and J.-M.S.-M. Writing—review and editing, L.-M.M.-D., J.-I.R.-G., and J.-M.S.-M. Supervision, L.-M.M.-D., J.-I.R.-G., and J.-M.S.-M. Project administration, J.-M.S.-M. Funding acquisition, J.-M.S.-M. All authors have read and agreed to the published version of the manuscript.

Funding: This publication is part of the research carried out within the research project “Diseño y elaboración de productos estratégicos diferenciados para la potenciación del turismo rural en Extremadura. De la detección de problemas a la propuesta de soluciones basadas en criterios geoestadísticos" (Code IB 16040). This project is funded by the Consejería de Economía e Infraestructuras de la Junta de Extremadura (the branch of the regional government that covers economy and infrastructure) and by the European Regional Development Fund (ERDF). 
Conflicts of Interest: The authors declare no conflicts of interest. The funders had no role in the design of the study, in the collection, analyses, or interpretation of data, in the writing of the manuscript, or in the decision to publish the results.

\section{References}

1. Montoya, M.I. La caza en el medievo peninsular. Revista Electrónica de Estudios Filosóficos 2003, 3. Available online: https://www.um.es/tonosdigital/znum6/portada/Cazamur.htm (accessed on 1 February 2020).

2. Valverde, J.A. Anotaciones al Libro de la Montería del rey Alfonso XI; Universidad de Salamanca: Salamanca, Spain, 2009; Volume 82.

3. López Ontiveros, A. Algunos aspectos de la evolución de la caza en España. Agricultura y Sociedad 1991, 58, 13-53. Available online: https://helvia.uco.es/bitstream/handle/10396/5594/a058_01.pdf?sequence=1 (accessed on 1 February 2020).

4. Bauer, J.; Herr, A. Hunting and fishing tourism. In Wildlife Tourism, Impacts, Management and Planning; Common Ground Publishing: Champaign, IL, USA, 2004; pp. 57-78. Available online: https://www. researchgate.net/publication/40871766 (accessed on 1 February 2020).

5. León, P.; Marías, D. El turismo cinegético. Abaco Revista de Cultura y Ciencias Sociales 2007, 54, 99-112.

6. Chapman, A.; Buck, W.J. La España Inexplorada; Consejería de Obras Públicas y Transportes: Sevilla, Spain, 1989; p. 456.

7. Rengifo Gallego, J.I. La oferta de Caza en España en el contexto del turismo cinegético internacional: Las especies de caza mayor. Ería 2008, 53-68. Available online: https://www.unioviedo.es/reunido/index.php/ RCG/issue/view/168/showToc (accessed on 1 February 2020).

8. U.S. Fish \& Wildlife Service. 2016 National Survey of Fishing, Hunting and Wildlife-Associated Recreation; U.S. Fish \& Wildlife Service: Falls Church, VA, USA, 2017; p. 24. Available online: https://www.fws.gov/ wsfrprograms/subpages/nationalsurvey/nat_survey2016.pdf (accessed on 1 February 2020).

9. European Federation for Hunter. Available online: https://www.face.eu/2016/09/hunting-in-europe-is-worth16-billion-euros/ (accessed on 1 February 2020).

10. Federation of Associations for Hunting and Conservation of the EU (FACE); Pinnet, J.M. The Hunters in Europe. Report; 1995; p. 12. Available online: https://www.kora.ch/malme/05_library/5_1_publications/P_ and_Q/Pinet_1995_The_hunters_in_Europe.pdf (accessed on 1 February 2020).

11. Danzberjer, J.B. La caza: Un elemento esencial en el desarrollo rural. Mediterráneo Económico: El nuevo Sistema Agroalimentario en una Crisis Global. 2009, Volume 15, pp. 183-203. Available online: https: //pdfs.semanticscholar.org/da63/600e9da6a5526375ec04bdde003393409bf9.pdf (accessed on 1 February 2020).

12. Lindsey, P.A.; Roulet, P.A.; Romanach, S.S. Economic and conservation significance of the trophy hunting industry in sub-Saharan Africa. Biol. Conserv. 2007, 134, 455-469. [CrossRef]

13. Călina, A.; Călina, J.; Miluț, M.; Stan, I. Research on the practice of rural tourism specialized in sport and image hunting in Cergău area, Romania. Agrolife Sci. J. 2018, 7, 18-24. Available online: http: //www.agrolifejournal.usamv.ro/pdf/vol.VII_1/Art2.pdf (accessed on 1 February 2020).

14. Martín-Delgado, L.M.; Rengifo-Gallego, J.I.; Sánchez-Martín, J.M. Hunting Tourism as a Possible Development Tool in Protected Areas of Extremadura, Spain. Land 2020, 9, 86. Available online: https://doi.org/10.3390/ land9030086 (accessed on 17 March 2020).

15. Saayman, M.; van der Merwe, P.; Saayman, A. The economic impact of trophy hunting in the south African wildlife industry. Glob. Ecol. Conserv. 2018, 16, e00510. [CrossRef]

16. Naidoo, R.; Weaver, L.C.; Diggle, R.W.; Matongo, G.; Stuart-Hill, G.; Thouless, C. Complementary benefits of tourism and hunting to communal conservancies in Namibia. Conserv. Biol. 2016, 30, 628-638. [CrossRef]

17. Casado, P.; Pérez, J.L.C.; Solano, S.E.; Román, C.P. El turismo cinegético: Una oportunidad sostenible para el turismo rural. Tour. Hosp. Int. J. 2015, 4, 89-104.

18. Tello-Leyva, Y.M.; Vázquez-Herrera, S.E.; Juárez-Reina, A.; González-Pérez, M. Turismo cinegético: Una alternativa sustentable? Eur. Sci. J. 2015, 11, 20. Available online: https://s3.amazonaws.com/academia. edu.documents/44029083/5949-17470-1-PB.pdf?response-content-disposition=inline\%3B\%20filename\% 3DTURISMO_CINEGETICO_UNA_ALTERNATIVA_DE_DE.pdf\&X-Amz-Algorithm=AWS4-HMACSHA256\&X-Amz-Credential=AKIAIWOWYYGZ2Y53UL3A\%2F20200317 (accessed on 1 February 2020). 
19. Mbaiwa, J.E. The socio-economic benefits and challenges of a community-based safari hunting tourism in the Okavango Delta, Botswana. J. Tour. Stud. 2004, 15,1-14. Available online: https://search.informit.com. au/documentSummary; dn=200501357;res=IELAPA;type=pdf (accessed on 1 February 2020).

20. Mbaiwa, J.E. Effects of Safari hunting tourism ban on rural livelihoods and wildfile conservation in Northern Botswana. S. Afr. Geograph. J. 2018, 41-61. [CrossRef]

21. Samuelsson, E.; Stage, J. The size and distribution of the economic impacts of Namibian hunting tourism. Afr. J. Wildife Res. 2007, 37, 41-52. [CrossRef]

22. Humavindu, M.N.; Barnes, J.I. Trophy hunting in the Namibian economy: an assessment. S. Afr. J. Wildlife Res. 24 Month Delayed Open Access 2003, 33, 65-70.

23. Muposhi, V.K.; Gandiwa, E.; Bartels, P.; Makuza, S.M. Trophy hunting, conservation, and rural development in Zimbabwe: issues, options, and implications. Int. J. Biodivers. 2016, 2016, 16. [CrossRef]

24. Booth, V.R. The Contribution of Hunting Tourism: How Significant is Th is to National Economies. In Contribution of Wildlife to National Economies; Joint Publication of FAO and CIC: Budapest, Hungary, 2010; p. 72.

25. Bielsa, J. La caza mayor como alternativa de desarrollo en zonas deprimidas de Extremadura. In Comunicaciones con motivo del I Congreso Internacional de caza en Extremadura; de Extremadura, J., La caza en Extremadura, Eds.; Diputacion Provincial de Cáceres: Cáceres, Spain, 1987; pp. 167-187.

26. Fischer, A.; Tibebe Weldesemaet, Y.; Czajkowski, M.; Tadie, D.; Hanley, N. Trophy hunters' willingness to pay for wildlife conservation and community benefits. Conserv. Biol. 2015, 29, 1111-1121. [CrossRef]

27. Sas-Rolfes, M. African wildlife conservation and the evolution of hunting institutions. Environ. Res. Lett. 2017, 11, 12. [CrossRef]

28. Rengifo, J.I.; Sánchez, J.M. Caza y espacios naturales protegidos en Extremadura. Investigaciones Geográficas 2016, 65, 57-73. [CrossRef]

29. Leader-Williams. Recreational Hunting, Conservation; Blackwell Publishing: Oxford, UK, 2009; p. 386.

30. Lovelock, B. Tourism and the Consumption of Wildlife: Hunting, Shooting and Sport Fishing; Routledge: London, UK, 2007; p. 313.

31. Heffelfinger, J.R.; Geist, V.; Wishart, W. The role of hunting in North American wildlife conservation. Int. J. Environ. Stud. 2013, 70, 399-413. [CrossRef]

32. Di Minin, E.; Leader-Williams, N.; Bradshaw, C.J. Trophy hunting does and will support biodiversity: a reply to Ripple et al. Trends Ecol. Evol. 2016, 31, 496-498. [CrossRef] [PubMed]

33. Marchand, P.; Garel, M.; Bourgoin, G.; Dubray, D.; Maillard, D.; Loison, A. Impacts of tourism and hunting on a large hervibore's spatio-temporal behavior in and around a French protected area. Biol. Conserv. 2014, 177, 1-11. [CrossRef]

34. Packer, C.; Brink, H.; Kissui, B.M.; Maliti, H.; Kushnir, H.; Caro, T. Effects of trophy hunting on lion and leopard populations in Tanzania. Conserv. Biol. 2011, 25, 142-153. [CrossRef] [PubMed]

35. Nogueras, J.J.R.; Caridad, J.M.; Gálvez, J.C.P. El perfil del turista cinegético: un estudio de caso para Córdoba (España). Int. J. Sci. Manag. Tour. 2017, 3, 187-203, 2386-8570.

36. Martín, L.M.; Rengifo, J.I.; y Sánchez, J.M. El turista cinegético. Una aproximación a su perfil en la comunidad autónoma de Extremadura. Investigaciones turísticas de la Universidad de Alicante 2019, 18, 193-219. [CrossRef]

37. Terrón, M. De la panorámica de la caza en Extremadura. C. Orellana (edit). Los libros de la caza española 1975, 473-520.

38. Terrón, M. De la Extremadura agreste: Notas para un estudio de la evolución histórica de la fauna de caza mayor. In La caza en Extremadura; Diputación de Cáceres: Cáceres, Spain, 1987.

39. Alvarado Corrales, E. Los espacios rurales y el ocio. Los Cotos de caza. In VIII Coloquio de Geógrafos Españoles. Comunicaciones; Asociación de Geógrafos Españoles: Barcelona, Spain, 1983; pp. 149-155.

40. Alvarado, E. La caza en Extremadura. Un recurso poco conocido. Agroexpo 1990, 3, 37-49.

41. Alvarado Corrales, E. Socieconomía de la caza. El ejemplo extremeño. In Manual de Ordenación y Gestión Cinegética; Formatex: Badajoz, Spain, 1991; pp. 21-54. Available online: www.dialnet.uniroja.es (accessed on 3 February 2020).

42. Alvarado Corrales, E. La actividad cinegética en Extremadura. Agricultura y Sociedad 1991, 58, $215-240$.

43. Calvo, S.; y García, M. Extremadura, Tradición de la Caza; Patronato de turismo de la Diputación Provincial de Cáceres: Madrid, Spain, 1988. 
44. Instituto Geográfico Nacional (2019): Base Topográfica Nacional 1:100 0000 . Available online: http: //centrodedescargas.cnig.es/CentroDescargas/index.jsp (accessed on 3 February 2020).

45. Gallardo, M.; Rodero, S.; Gómez, M.; Gallardo, J.M.; Arroyo, V.; Durán, J.A. Situación de la caza en Extremadura: Informe Anual Temporada 2016/17; Federación Extremeña de caza: Badajoz, Spain, 2018; Available online: https://cazawonke.com/wp-content/uploads/2018/09/INFORME-ANUAL-CAZA.pdf (accessed on 1 February 2020).

46. Morales, P.; Rodríguez, L. Aplicación de los coeficientes correlación de Kendall y Spearman. In Barquisimeto; Universidad Centroccidental Lisandro Alvarado: Venezuela, Spain, 2016.

47. Sastre, A.; Payeras, M. Diferencias en el perfil del turista de la temporada alta y baja. In XVIII Reunión Anual Asepelt 2004; Universitat de Les Illes Balears: Palma, Spain, 2004; Available online: https://scholar.google.es/scholar?hl=es\&as_sdt=0\%2C5\&q=47.\%09Sastre $\% 2 \mathrm{C}+\mathrm{A} . \% 3 \mathrm{~B}+$ Payeras $\% 2 \mathrm{C}+$ M.+Diferencias+en+el+perfil+del+turista+de+la+temporada+alta+y+baja.+In+XVIII+Reuni $\%$ C $3 \%$ B3n+Anual+Asepelt+2004\%3B+Universitat+de+Les+Illes+Balears $\% 3 \mathrm{~A}+2004 . \& b t n G=$ (accessed on 3 February 2020).

48. Arizón, M.J.B.; Garcés, S.A.; Sangrá, M.M. Perfil del turista de festivales: el caso del Festival Internacional de las Culturas Pirineos Sur. Cuadernos de Turismo 2012, 30, 63-90. Available online: http://hdl.handle.net/10201/ 29319 (accessed on 3 February 2020).

49. Folgado, J.A. y Hernández. El perfil del turista de eventos culturales: análisis exploratorio. Cultura, desarrollo y nuevas tecnologías: VII Jornadas de investigación. 2014, pp. 57-74. Available online: https://idus.us.es/bitstream/handle/11441/77064/El\%20perfil\%20del\%20turista\%20de\% 20eventos\%20culturales.pdf;jsessionid=C07CDD8E165CC6F629690C1790C75BA2? sequence=1 (accessed on 3 February 2020).

50. Junta de Extremadura. Plan General de Caza en Extremadura; Junta de Extremadura: Mérida, Mexico, 2015; Available online: http://extremambiente.juntaex.es/files/Informacion\%20Publica/2015/octbre/Anteproyecto\% 20PGCEx\%20-\%20optimizado.pdf (accessed on 5 February 2020).

51. Andueza, A.; Lambarri, M.; Urda, V.; Prieto, I.; Villanueva, L.F.; Sánchez-García, C. Evaluación del Impacto Económico y Social de la Caza en Castilla-La Mancha; Fundación Artemisan: Ciudad Real, Spain, 2016; p. 76. Available online: https:/www.fundacionartemisan.com/wp-content/uploads/2018/04/Resumen-Ejecutivo. pdf (accessed on 5 February 2020).

52. Consejería de Medio Ambiente y Rural, Políticas Agrarias y Territorio. ORDEN de 21 de agosto de 2017 General de Vedas de Caza para la temporada 2017/2018, de la Comunidad Autónoma de Extremadura. 2017. Available online: http://doe.gobex.es/pdfs/doe/2017/1630o/17050355.pdf (accessed on 5 February 2020).

53. Consejería de Agricultura, Desarrollo Rural, Medio Ambiente y Energía. DECRETO 91/2012, de 25 de mayo, por el que se aprueba el Reglamento. 2012. Available online: http://doe.gobex.es/pdfs/doe/2013/1040o/ 13040100.pdf (accessed on 5 February 2020).

54. Consejo Económico y Social, de. Reto demográfico y equilibrio territorial en Extremadura; Junta de Extremadura: Mérida, Mexico, 2019; p. 311.

55. Martín, L.M.; Rengifo, J.I. y Sánchez, J.M. El modelo de caza social: evolución y caracterización en Extremadura. Boletín de la Asociación de Geógrafos Españoles 2019, 82, 1-37. [CrossRef]

(C) 2020 by the authors. Licensee MDPI, Basel, Switzerland. This article is an open access article distributed under the terms and conditions of the Creative Commons Attribution (CC BY) license (http://creativecommons.org/licenses/by/4.0/). 